\title{
Ideology and the Study of Judicial Behavior
}

\author{
Lee Epstein, Andrew D. Martin, Kevin M. Quinn, and Jeffrey A. Segal
}

The role of ideology in the study of political behavior has a long and distinguished history. Whether writing in the 1940s, the 2000s, or eras in between, political scientists have examined the assumption that the ideological commitments of the masses and elites alike help explain the political choices they make-from their willingness to support particular public policies to the votes they cast. ${ }^{1}$ As James L. Stimson (1991), the eminent student of public opinion, puts it, "Ideology won't go away. It is too important" (p.61). ${ }^{2}$

With even less controversy, we can say that political scientists-and increasingly, legal academics - who study judging tend to share the idea that explanations of judicial behavior that fail to incorporate ideology are incomplete at best.

This chapter begins with a brief description of the role ideology plays in political science accounts of judging. Parts II and III turn to the challenges scholars confront when empirically assessing judicial decision making and the methods political scientists have developed to meet these challenges. While much work remains, the field has advanced markedly since its founding in the $1940 s,{ }^{3}$ as evidenced by a plethora of interesting research results in recent years. Part IV provides an overview of some of the more prominent findings.

\section{THE ROLE OF IDEOLOGY IN POLITICAL SCIENCE ACCOUNTS OF JUDGING}

Ask 10 law professors to articulate a theory of judging and you are likely to receive 10 different responses. The same is true of political scientists. No one theory of judging, much less a unifying paradigm, dominates the field. On the other hand, in virtually all political science accounts of judicial decisions, ideology plays an important, if not central, role. ${ }^{4}$

In a nutshell, political scientists see judges as attempting to maximize their ideological preferences by bringing the law in line with their own political commitments. ${ }^{5}$ Judges accomplish this mission, according to some political science accounts, by voting on the basis of their sincerely held ideological attitudes 
vis-à-vis the facts of cases, and nothing more. ${ }^{6}$ In other words, Justice Scalia "votes the way he does because he extremely is conservative; Justice Marshall voted the way he did because he was extremely liberal" (Segal \& Spaeth, 2002, p. 86). On other political science accounts, justices seek to achieve their policy goals by acting strategically - that is, by taking into account the preferences and likely actions of actors who are in position to thwart the achievement of their political objectives, including Congress, the president, and their own colleagues. $^{7}$

These two accounts may differ in their details, but they do not veer in their emphasis on politics as opposed to "law." Neither posits judges as neutral, principled decision makers; instead, both subscribe to Stimson's general view that ideology is a driving force in politics-including on the bench. ${ }^{8}$ Seen in this way, they offer a fundamentally different take on judging from traditional "legalistic accounts," which do not recognize a role for ideology.

This is not to say that legal methods-whether appeals to text, precedent, history, and so on-play no role in ideological accounts of judging; very few political scientists would go that far. It is, rather, to say that on most political accounts, legal factors come into play as constraints on judges and not as motivating forces.

To see the point, consider federal trial court judges. Political scientists would say that these judges are no different from all other judges: they would like to see the law reflect their own ideological values. But, like all other judges, they face several constraints along the way. For example, if trial judges fail to take into account precedent established by their judicial superiors, they run the risk of reversal-in which case the higher court could supplant trial judges' most favored rule with their least favored alternative (e.g., Randazzo, 2008; Schanzenbach \& Tiller, 2007). Note that the trial judges in this example do not attend to precedent for the sake of attending to precedent. Rather, they follow it in an effort to maximize their policy preferences, to avoid adoption of their least favored rule. In other words, the doctrine of stare decisis-or, more pointedly, the judicial hierarchy-acts as a constraint on the judges' policy preferences and is not a goal in and of itself.

In addition to legal factors that may serve as limitations on judges' pursuit of their ideological goals, literature in political science (and, increasingly, in law-e.g., Posner, 2008; Sunstein, Schkade, Ellman, \& Sawicki, 2006) considers other forces that may constrain the ability of judges to vote sincerely, including the preferences and likely actions of elected actors (Eskridge, 1991a, 1991b; Bergara, Richman, \& Spiller, 2003), the judges' colleagues, (Sunstein et al., 2006; Cross \& Tiller, 1998), and the public (especially for judges who must be reelected to keep their job; Brace \& Boyea, 2008; Huber \& Gordon, 2004). 
But, yet again, many political scientists argue that in the absence of these constraints the judges would do exactly what they want, which is to bring the law in line with their ideological values.

Of course, it is one thing to state the political science claim about the prevalence of ideology and quite another to test it. Two challenges stand out: characterizing the ideology of judges, which is the topic of part II, and characterizing the ideology of their decisions, which is taken up in part III.

\section{THE IDEOLOGY OF JUDGES}

For most studies, characterizing the ideology of judges basically boils down to determining whether they are liberal, conservative, or something in between. Early on, scholars undertook this task by relying on a judge's party affiliation or, more typically (for federal judges), the party of the appointing president. Judges appointed by Republican presidents, or who are Republicans themselves, are thought to be more conservative than Democratic appointees.

This party-based approach has several nice features. Primarily, it produces high intercoder agreement: if the coders had a list of the party affiliation of every president (or every judge) and knew which president appointed a particular judge, no judgment calls are required. ${ }^{9}$

The high degree of reliability may explain why partisanship remains a common surrogate for ideology in some circles. ${ }^{10}$ But many political scientists have questioned whether party-based approaches are valid-that is, whether they accurately capture the concept of ideology. Along these lines, critics point to four troublesome assumptions underlying the approach. The first assumption is that all Republican presidents (or judges) are conservatives and all Democratic presidents (or judges) are liberal. However, data tend to show otherwise. On one measure of economic liberalism, for example, Jimmy Carter was ideologically closer to Richard Nixon than to Lyndon Johnson. ${ }^{11}$ Or as Giles and his colleagues put it, "presidents of the same political party vary in their ideological preferences. Eisenhower is not Reagan. Indeed, the empirical record demonstrates that the voting propensities of the appointees of some Democratic and Republican presidents do not differ significantly" (Giles, Hettinger, \& Peppers, 2001, p. 624; see Songer \& Haire, 1992). ${ }^{12}$ A second assumption-that all presidents are motivated to appoint judges who reflect their ideology-also fails to comport with various studies delineating other presidential goals. To provide but one example, Ronald Reagan's appointment of Sandra Day O'Connor was less about advancing ideological goals than about appealing to female voters. ${ }^{13} \mathrm{~A}$ third crucial assumption is that a judge's ideology is stable. If it is not, the static measure of the judge's or president's party 
affiliation would fail to capture any changes. As it turns out, though, this assumption does not typically hold. Several recent studies of Supreme Court justices reveal substantial ideological drift over time, as we explain in part II (Martin \& Quinn, 2007; Epstein, Martin, Quinn, \& Segal, 2007). Fourth, partybased approaches assume that the president controls judicial nominations. For federal appellate and trial court judges, however, this assumption neglects an important institutional feature of the appointment process - called "senatorial courtesy" - which may constrain the president from nominating a candidate to the lower federal courts who mirrors his ideology (Giles et al., 2001). Under courtesy norms, when a senator is of the same party as the president and the vacancy is from the senator's state, the senator can exert considerable influence on the selection of judges.

In light of these concerns, political scientists have devised several alternative measures of judicial ideology. Some measures are exogenous, meaning they are not based on the votes judges cast or other choices they make. ${ }^{14}$ Other measures are endogenous, meaning they are derived, at least in part, from those votes. Exogenous measures are useful for causal accounts; endogenous measures have the benefit of greater precision. The choice between the two depends largely on the goals of the study.

When the goal is to explain the effect of ideology on the judges' votes, scholars typically prefer exogenous measures because explaining votes with measures derived (even in part) from those very same votes involves a degree of circularity. For example, if we classify Scalia as conservative because he casts conservative votes, all we can say is that Scalia's votes predict his votes. But in studies that take the effect of ideology as a given and wish to describe how it works (for example, whether liberals or conservatives are most likely to support First Amendment values; whether ideology changes over time), endogenous approaches may be preferable because they are more precise. Let us elaborate.

\section{A. Exogenous Measures}

For justices of the U.S. Supreme Court, political scientists have proposed a number of exogenous measures-measures that are based on information that is causally prior to any votes being cast-to capture ideology, but the most popular approach has been the Segal-Cover scores. Two political scientists, Segal and Cover (1989), derived these scores by content-analyzing newspaper editorials written between the time of the justices' nomination to the U.S. Supreme Court and their confirmation. Specifically, Segal and Cover trained students to code each paragraph in the editorial for political ideology as follows: 
Paragraphs were coded as liberal, moderate, conservative, or not applicable. Liberal statements include (but are not limited to) those ascribing support for the rights of defendants in criminal cases, women and racial minorities in equality cases, and the individual against the government in privacy and First Amendment cases. Conservative statements are those with an opposite direction. Moderate statements include those that explicitly ascribe moderation to the nominees or those that ascribe both liberal and conservative values. (p. 559)

Segal and Cover then measured judicial ideology by subtracting the fraction of paragraphs coded conservative from the fraction of paragraphs coded liberal and dividing by the total number of paragraphs coded liberal, conservative, and moderate. The resulting scale of policy preferences ranges from 0 (unanimously conservative) to .5 (moderate) to 1 (unanimously liberal). Figure 20.1 displays the results for Justices appointed since 1953.

It is easy to see why many scholars invoke these scores. First, with only a few exceptions (for instance, Warren seems more liberal than his score; Thomas seems more conservative than his), the overall results comport with scholarly

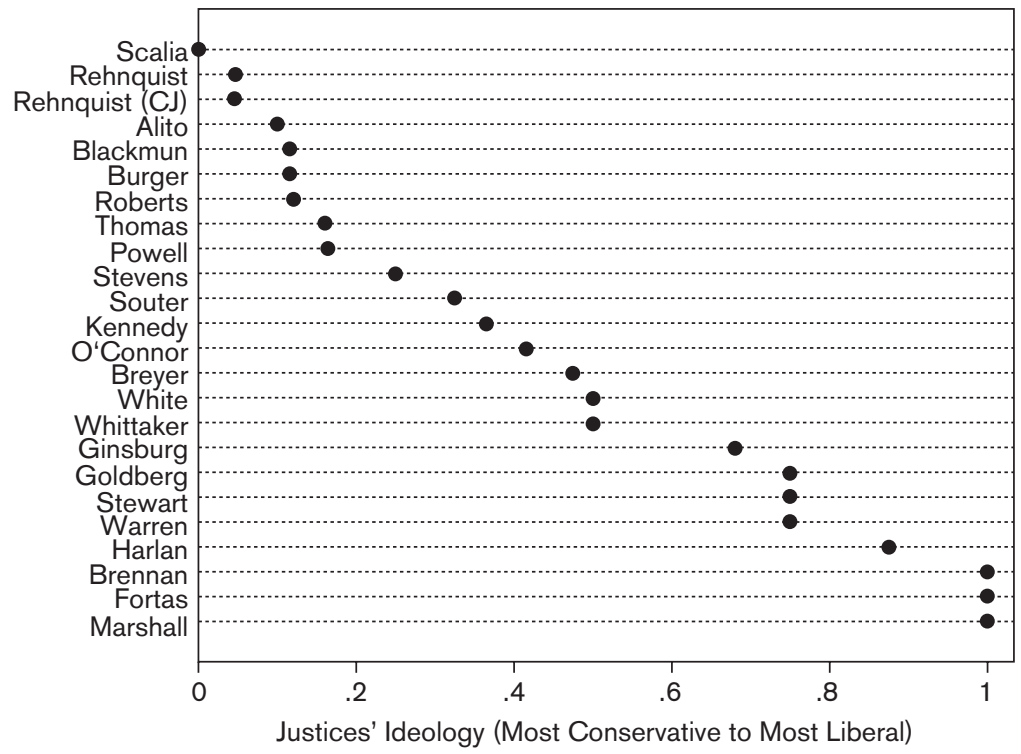

Figure 20.1 Ideology of Supreme Court Justices Appointed Since 1953, Based on Newspaper Editorials

Note: Data available in Epstein et al. (2007) and at http://www.sunysb.edu/ polsci/jsegal/qualtable.pdf. 
impressions of the justices. Brennan and Marshall, generally regarded as liberals, receive scores of 1.00; Scalia and Rehnquist, generally regarded as conservatives, receive scores of 0 and .045 , respectively. Second, the Segal-Cover scores do not appear to systematically over- or underestimate liberal votes. For most justices, the statistical fit between their scores and their votes is quite good, with a .79 overall correlation between the two (see figure 20.6, later).

Despite the many desirable properties of the Segal-Cover scores, they are not without drawbacks. One is that they are better surrogates for ideology in cases involving civil rights and liberties than in litigation in areas such as federal taxation and federalism (Epstein \& Mershon, 1997). This is hardly a surprise. When evaluating the ideology of would-be justices, newspaper editors-on whose judgment Segal and Cover (1989) rely—are far more likely to focus on, say, capital punishment than on changes to the tax code. Second, just as some analysts critique partisan measures for being static, we could level the same charge at the Segal-Cover scores: once computed they do not vary over the course of an individual justice's career. Were only one or two justices to change over time, this would not be a particularly troublesome. But new research shows that virtually all the justices serving since 1937 grew more liberal or conservative during their tenure on the Court (Epstein et al., 2007). Figure 20.2 illustrates one of the more extreme examples: Harry Blackmun's nearly complete flip, from one of the Court's most conservative members to among its most consistent civil libertarians. Obviously an ideological score developed in 1970 would not be especially useful in predicting Blackmun's votes two decades later, in 1990. To greater and lesser extents, we could say the same of many of the other justices.

A final issue with the Segal-Cover scores is that the approach is limited to Supreme Court justices. Owing to a shortage of newspaper editorials, scholars have found it unfeasible to calculate ideological scores for judges serving in the lower federal courts or on state benches.

Perhaps analysts could eventually rely on blog discussions of lower court judges to perform much the same function as newspaper editorials. In the meantime, they have turned to other approaches. The state-of-the-art measure for the ideological preferences of U.S. Court of Appeals judges (and, for that matter, federal District Court judges), developed by Giles and his colleagues, exploits the norm of senatorial courtesy—the very norm that partisan measures ignore. ${ }^{15}$ If a judge is appointed from a state where the president and at least one homestate senator are of the same party, the nominee is assigned the ideology of the home-state senator. If both senators are from the president's party, the nominee is assigned the average ideology of the home-state. If neither home-state senator is of the president's party, the nominee receives the ideological score of the 


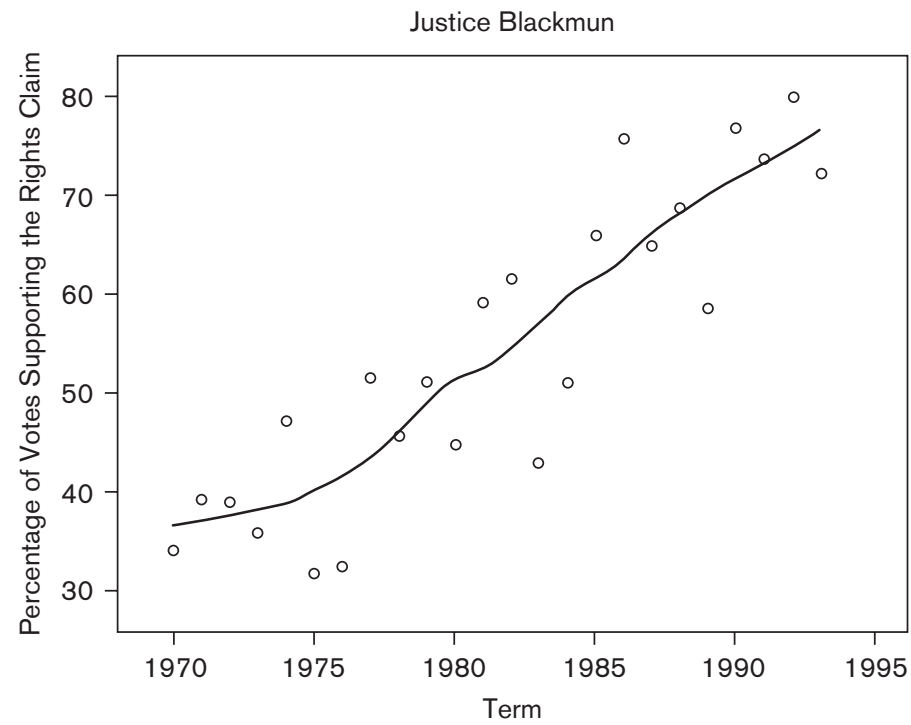

Figure 20.2 Support for Civil Liberties Claims: The Career Voting Record of Justice Harry A. Blackmun

Note: This figure reports the percentage of votes cast each term in which Justice Blackmun supported defendants in criminal cases; women and minorities in civil rights cases; and individuals against the government in First Amendment, privacy, and due process cases. The superimposed line is a first-degree loess smooth with $\operatorname{span}=0.45$.

appointing president (Giles et al., 2001). ${ }^{16}$ In short, when courtesy is in effect, the federal judge receives the ideology of the "nominating" senator; when courtesy is not in effect, the judge receives the score of the nominating president.

Seen in this way, the approach taken by Giles, Hettinger, and Peppers (2001) is far more efficient than party-based approaches because it incorporates important information about how federal judges are appointedinformation that party-based approaches disregard. On the other hand, it suffers from a problem that plagues many exogenous measures: it is static and so cannot account for ideological drift. It also assigns all judicial nominees from the same state and year the same ideology.

\section{B. Endogenous Measures}

To overcome the shortcomings of these exogenous measures, as well as to generate more precise estimates of ideology, social scientists have proposed several endogenous approaches. Endogenous approaches depend on 
revealed behavior to measure ideology (Epstein \& Mershon, 1997). Virtually all current work on the Supreme Court makes use of Andrew D. Martin and Kevin Quinn's estimates of the justices' ideologies. Derived from analyses of voting patterns on the Supreme Court each term-meaning that the justices' ideologies can and do change over time-the Martin-Quinn scores are theoretically unbounded. For justices serving in the modern era, they range from a very liberal -6 (Justice Douglas) to a very conservative +4 (Justice Thomas). ${ }^{17}$

Figure 20.3 underscores these last two points about the range and dynamic nature of the Martin-Quinn approach. The figure provides ideological estimates for justices serving on three courts, in 1963, 1983, and 2003. Note, first, the range from an exceptionally liberal Justice Douglas in the 1963 term to the exceptionally conservative Justice Thomas in the 2003 term. Now consider the dynamic character of the estimates, such that Justice Brennan's ideological
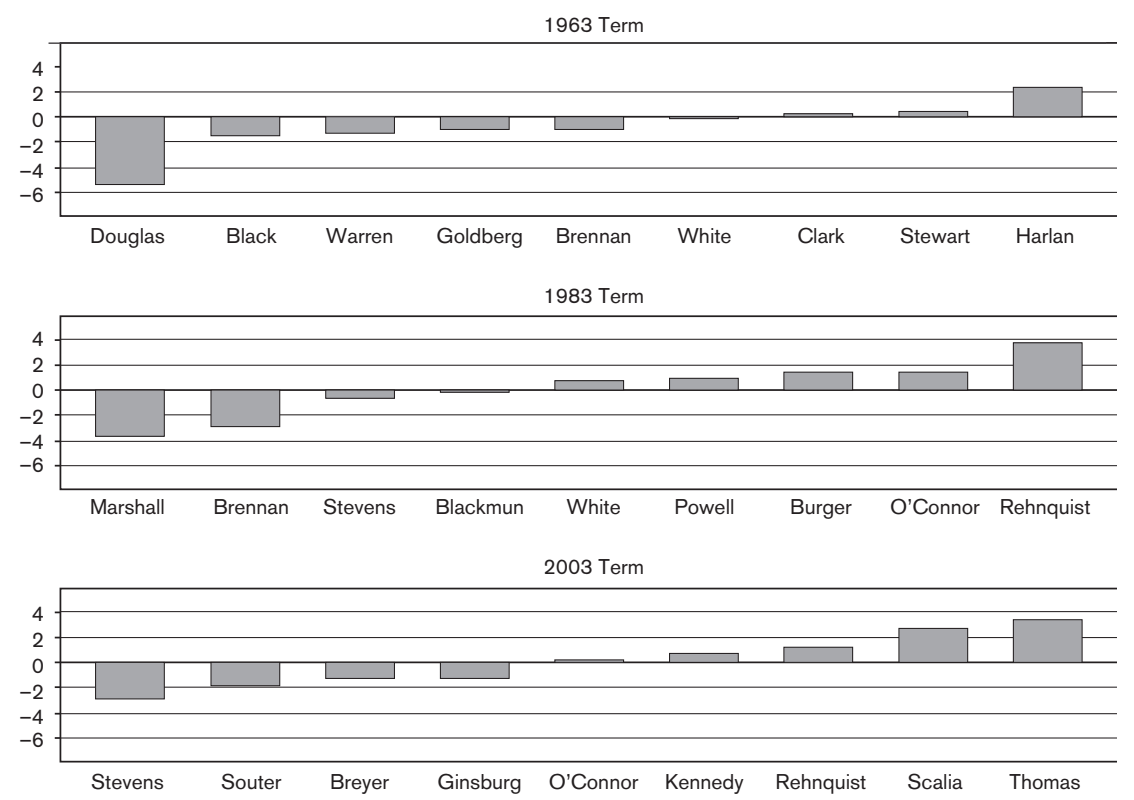

Figure 20.3 Martin \& Quinn's Estimates of the Justices' Ideologies for the 1963, 1983, 2003 Terms

Note: We have ordered (on the horizontal axis) the justices serving during each term from most liberal to most conservative based on the Martin-Quinn estimates of their ideology, which are depicted on the vertical axis. The vertical axes run from most liberal (here, shown as -6 ) to most conservative (shown as +4 ). 
estimate of -.83 in 1963 was considerably more moderate than the 1983 estimate of -2.82 . Rehnquist was more moderate during his penultimate term as chief (in 2003) than during his associate days (1983 term).

Even from this brief description of the Martin-Quinn scores, their usefulness becomes more apparent. Because they are based on analyses of readily available data-vote patterns - they are susceptible to replication. They also square with our overall impressions of the ideology of the justices. In figure 20.3, notice, for example, that Justices Scalia and Thomas, generally considered the most reliably conservative members of the Rehnquist Court (and now the Roberts Court), anchor the right end and Justices Stevens and Ginsburg, the left end. Finally, as we just noted, Martin-Quinn scores overcome a major weakness of most exogenous measures: they are dynamic, enabling reliable and valid measurements of the justices' ideologies even if their ideologies drift with time.

On the other hand, the Martin-Quinn approach suffers from the same problems as other endogenous measures: because researchers derive their estimates from votes, deploying these scores to study the effect of ideology on votes would amount to using votes to predict votes. One response is that researchers should use them only for certain kinds of studies-typically studies that already assume ideology has an effect on voting. Endogenous scores, for example, have been used in research on ideological drift, which asks whether justices' ideologies change with time.

Another response to this endogeneity problem is to remove the cases of interest from the data and then estimate Martin-Quinn scores. Suppose we wanted to study the effect of ideology on votes in First Amendment cases. By purging the First Amendment cases and recalculating the scores, we would avoid the trap of using votes to predict votes.

At one level, this technically resolves the circularity problem, though this aspect of the problem can be overstated. As Martin and Quinn (2005) write,

[A]s a practical matter using the full data Martin-Quinn scores when modeling votes in a single issue is perfectly appropriate. While circularity is a technical concern, the resultant measures from purging issues will change very little, and so it is not worth the effort to do so. When modeling votes in a single issue area, circularity is not a practical concern. (p. 3)

But that response does not resolve a related problem as to what causes the justices' votes in the first place. Let's say we are interested in the role of ideology in explaining the justices' First Amendment votes. If we exclude First Amendment votes in the calculation of the Martin-Quinn scores, we have eliminated the circularity question. But it introduces the question as to what 
caused the non-First Amendment votes in the first place. Ideology is a possible cause, but all we can really know is that the same factors that influence the justices' non-First Amendment votes influence their First Amendment votes.

Nevertheless, these scores are descriptively more accurate than any of the exogenous measures-that is, on a term-by-term basis, they provide a more illuminating picture of the justices' ideological preferences than either the Segal-Cover scores or party-based measures. So if scholars need to know who the median justice is, or whether the Chief Justice overassigns opinions to justices ideologically close to him, then these scores substantially outperform exogenous measures.

\section{THE IDEOLOGICAL CONTENT OF CASES}

Assessing political science accounts of judging requires more than estimating the judges' ideologies. Also crucial to this enterprise is classifying the ideological content of judicial decisions. In other words, if we want to claim that a liberal judge will cast a liberal vote, not only do we need to know whether the judge is liberal or not but we also need to know what a liberal vote means.

Harold J. Spaeth, a political scientist and law professor, offers a potential solution. In the late 1980s, he developed the U.S. Supreme Court Judicial Database, which contains hundreds of pieces of information about each case, including whether the Court's decision (and each justice's vote) was liberal or conservative. For the most part, Spaeth's definitions comport with conventional usage. ${ }^{18}$ "Liberal" decisions or votes are those in favor of defendants in criminal cases; of women and minorities in civil rights cases; of individuals against the government in First Amendment, privacy, and due process cases; of unions over individuals and individuals over businesses in labor cases; and the government over businesses in economic regulation. "Conservative" decisions and votes are the reverse.

Spaeth's approach meets a very important criterion in the social sciences: reliability. That is, using Spaeth's definitions, scholars can replicate his results. Nonetheless, some have taken issue with the definitions themselves, pointing out that while Spaeth's classifications are clear, it is not clear that complex cases always fit neatly into one category or the other. Take Wisconsin v. Mitchell (1993), in which the Court upheld a state law that increased the sentence for crimes if the defendant "intentionally selects the person against whom the crime is committed" on the basis of race, religion, national origin, sexual orientation, or other similar criteria. If we view the law as penalizing racial or ethnic hatred, we would count it as defending civil rights (a "liberal" 


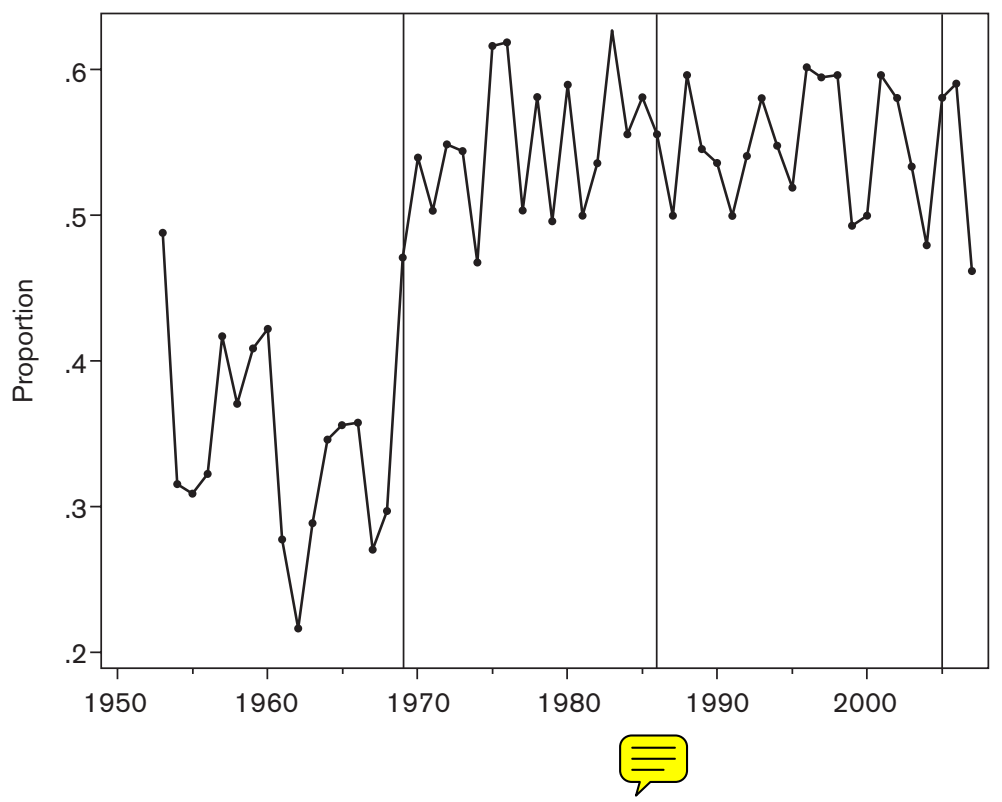

decision). If, however, we see the law as penalizing a person because of what she believes or says, we would deem the ruling anti-rights (a "conservative" decision).

There are other potential problems. ${ }^{19}$ But most behavioral studies of judging - whether at the federal or state level—have adopted Spaeth's definitions. There are two major factors explaining the widespread use of this measure. First, Spaeth's results square with general expectations of what is liberal and conservative. Consider figure 20.4, in which we show the fraction of conservative decisions rendered by the Supreme Court since 1953. Note the marked change in the 1969 term, coinciding with Nixon's replacement of Earl Warren with Warren Burger. Within one year, the proportion of right-of-center decisions increased by over 50\%, from .30 in 1968 to .47 in 1969. Moreover, in comparing the overall means of conservatism during the two Court eras-the Warren Court (.34) and Burger Court (.55) - the difference, not surprisingly, is statistically significant. ${ }^{20}$ This pattern comports with modern-day writings on the Court, as does the relatively stable degree of conservatism after the 1969 term.

Second, at least some of the problems scholars have suggested with Spaeth's approach are, in actuality, fairly trivial. Returning to Wisconsin v. Mitchell, the critique was that the case has two dimensions-race and speech-and so deciding whether it is a liberal or conservative decision depends on whether 
one codes it as a race case or a speech case. But as it turns out, cases like Wisconsin are something of an oddity. A rather large body of literature tells us that a single left-right dimension underlies virtually all Supreme Court cases in virtually all areas of the law. ${ }^{21}$

For many studies of judging, Spaeth's approach is the end of the matter. Based on his definitions of ideology (or adaptations of them), scholars classify decisions as "liberal" or "conservative." This approach works well for studies of individual judges in which we want to know, for example, whether the judge voted in accord with his ideology. However, some critics say improvements are needed in the study of court decisions.

Again, consider the Supreme Court and suppose that the justices are aligned ideologically as indicated in figure 20.5. Further suppose that they issue a decision favoring the state in a death penalty case, with Justice Kennedy writing for a five-person majority (Alito, Roberts, Scalia, and Thomas).

Under Spaeth's approach, we would designate the decision as "conservative" because it favored the state rather than the defendant. But that approach fails to make use of several pieces of important information-the content of the majority opinion and the identity of the members of the majority, both of which may be useful in developing a more precise understanding of the decision's ideological content. Rather than simply code the decision as "liberal" or "conservative," we might use computer-based codings to categorize the opinion along a more precisely measured scale. Roe v. Wade and Planned Parenthood v. Casey are both liberal decisions under Spaeth's codings, but Roe is certainly more liberal than Casey. Computer programs such as Wordscore can assist in measuring these differences (McGuire \& Vanberg, 2005). Alternatively, we could assign the opinion the Martin-Quinn score of the median member of the majority (Jacobi, 2009). Another possibility would be to focus on the ideology of the majority opinion writer.

Deciding precisely how to proceed depends on one's theory of decision making. As computer-based systems improve, scholars will increasingly rely on them. For now, those who believe in a strong version of the median voter theorem might be inclined to classify the ideology of the decision on the basis of the median member of the majority. Following theories of agenda setting,

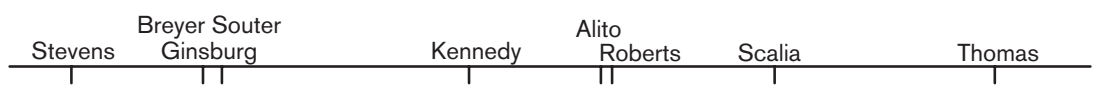

Figure 20.5 Martin-Quinn Estimates for Supreme Court Justices, 2007 Term Note: We have arrayed the justices from most liberal (Stevens) to most conservative (Thomas) based on their 2007 Martin-Quinn scores. 
on the other hand, using the opinion writer's ideological score might make more sense. Either way, some argue that these approaches have the potential to provide a finer-grained understanding of Court decisions, which analysts could apply to any collegial decision-making body.

\section{A (VERY) SMALL SAMPLE OF RESEARCH FINDINGS}

A full review of the research findings on judging and ideology would take more pages than are in this entire volume. What we can do instead is provide the flavor of some of the more prominent findings.

One important set of data focuses specifically on the simple relationship between votes and judging. Figure 20.6 tells the basic story at least for the

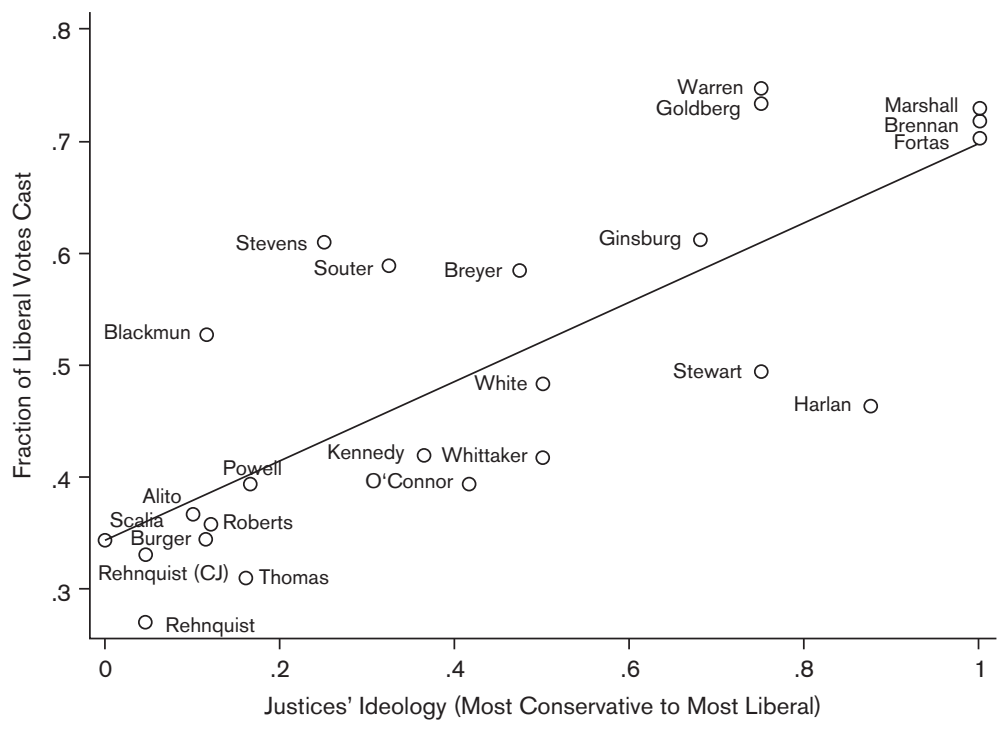

Figure 20.6 Relationship between Newspaper Editors' Characterizations of the Justices' Ideology Prior to Their Appointment and the Justices' Votes, 19532007 Terms

Note: The superimposed line represents a regression-based prediction of the justices' votes based on their ideology, as measured by the Segal-Cover scores. Data on the votes of the justices come from the U.S. Supreme Court Judicial Database using all orally argued cases. The closer a justice is to the line, the stronger the association between the justice's ideology and the justice's votes. The justices above the line voted more liberally than we would predict based on their ideology; the justices below it voted more conservatively. For justices on the line, their ideology perfectly (or nearly so) predicts their votes. The correlation between the justices' ideologies and their votes is .79. 
Supreme Court: regardless of whether we use the Segal-Cover or MartinQuinn scores to measure of ideology, a strong relationship exists between ideology and votes. The correlation of .79 reflected in figure 20.6 is not at all atypical.

Turning to other courts substantially changes the picture. A now extensive body of literature on the U.S. Courts of Appeals reveals that the ideological preferences of the judges, however measured, provide only a partial explanation of their decisions and then only in some areas of the law. A landmark study conducted by Sheldon Goldman in 1966 indicated that federal circuit court judges affiliated with the Democratic Party were, relative to Republican judges, far more likely to vote for unions in labor-management disputes and against corporations charged with antitrust violations. But Goldman found no statistically significant differences between Democratic and Republican judges in the areas of criminal law and civil liberties, nor in challenges to government regulations brought by businesses. For example, judges appointed by Lyndon Johnson were no more likely to rule in favor of criminal defendants than judges appointed by Dwight Eisenhower.

More recent work by Cass Sunstein and his colleagues (2006) confirms Goldman's (mixed) findings. To be sure, their examination of more than 19,000 votes cast by Court of Appeals judges unearthed strong evidence of partisan voting in many areas of the law. In affirmative action suits, for example, judges appointed by Republican presidents rarely voted to uphold the plan at issue, doing so in less than $50 \%$ of disputes. By contrast, Democratic appointees supported the plan in three out of every four cases. Yet in 5 of the 24 areas of the law analyzed, the party of the appointing president was not an especially good predictor of the judge's vote. In criminal cases, Democratic appointees were no more or less favorable toward defendants than Republican appointees. Likewise, for all but abortion and capital punishment, the judge's vote was affected not only by his ideology but also by the ideology of the colleagues with whom he sat. All-Democratic panels vote to uphold affirmative action plans in $81 \%$ of the cases, but when a Democratic appointee sits with two Republicans he votes to support the plan only $60 \%$ of the time. Likewise, all-Republican panels vote to strike plans in $66 \%$ of the cases, but a Republican sitting with two Democrats opposes them in only $30 \%$ of the cases. According to Sunstein and his collaborators (2006), both are clear examples of "ideological dampening."

Finally, Segal's research looks at the relationship between ideology and voting in the Court of Appeals, using the ideology scores set by Giles, Hettinger, \& Peppers (2001), rather than the judges' political party. As shown in figure 20.7, while the relationship between the judges' ideologies and their 




Figure 20.7 The Relationship between the Ideology of U.S. Court of Appeals Judges and their Votes

Note: Each dot represents a judge. The closer a judge is to the regression line, the better her ideology (as measured by the Giles et al. scores) corresponds to her votes. The correlation between ideology and votes is .39 .

votes is reasonably strong (.39), ideology is a far worse predictor for lower court judges than it is for Supreme Court justices. As Segal (2008) concluded, "obviously much more is at work on the Court of Appeals than just ideology" (p. 28). Perhaps this other work might include "easy" cases where there is little room for ideological voting (those in which the law is clear (Howard, 1981), or in which issues lack ideological valence (Sunstein et al., 2006) or are constrained by the judge's circuit or by the Supreme Court (Kim, 2009).

Still, it is possible that Segal's findings underestimate the impact of ideology. One problem could trace to measurement error in the Giles, Hettinger, and Peppers (2001) data, which would have the effect of dampening the observed relationship (e.g., King, Keohane, \& Verba, 1994). For example, while the Giles, Hettinger, and Peppers (2001) scores improve upon partybased scores by taking advantage of senatorial courtesy, the actual application of courtesy varies from state to state and from appointment to appointment. For example, Democratic Senator Patrick Moynihan and Republican Senator Alfonse D'Amato agreed to split judicial nominations between them, with the senator of the president's party receiving three-quarters of the picks (Johnson, 
1993). During Republican administrations, judges received D'Amato's ideology score even if Moynihan named them. During Democratic administrations, judges received Moynihan's ideology score, even if they came from D'Amato's list. Or consider the moderate ideology score attributed to conservative Court of Appeals Judge Richard Posner. Posner received the ideology score of moderate Republican Senator Charles Percy. However, the Reagan White House imposed Posner's nomination on Senator Percy over Percy's opposition, so applying Percy's moderate score to Posner is likely inaccurate (Anderson, 1981). In short, while the revealed correlation of .39 indicates a reasonably strong link between ideology and behavior, ideology scores with less measurement error would undoubtedly find an even stronger relationship.

Even accounting for measurement error, though, the findings are likely to remain relatively mixed for courts below the Supreme Court. This should not be altogether surprising. On one hand, we would not expect ideology or partisanship to play absolutely no role in judging on the appellate bench. If this were the case, no one would care much whether a Democrat or Republican won the presidency - at least not with regard to judicial selection. Their judicial nominees would be essentially fungible, which the literature tells us is not the case. On the other hand, the lack of ideological voting in some areas is not difficult to explain: lower court judges face greater constraints in attempting to etch their ideology into law. Part 1 mentioned the threat of reversal by judicial superiors, but many other constraints exist, including the desire for promotion to a higher judicial office. For ambitious appellate court judges, it may not be in their best interest to ignore organizational norms such as stare decisis and decide purely on the basis of their ideology.

Studies like those depicted in figures 20.1 and 20.7 seek to identify a direct link between the judges' ideologies and their votes. Extant research also has considered ideological patterns in other choices judges make, such as the decision to overrule a precedent. Perhaps not surprisingly, scholars have shown that conservative justices are more likely to vote to overrule precedents that liberals favor, such as Roe v. Wade, and liberal justices to overrule conservative precedents, such as Bowers v. Hardwick (Hansford \& Spriggs, 2006; Brenner \& Spaeth, 1995). The justices' votes to overturn federal, state, and local laws seem equally ideological. Segal and Spaeth (2002) unearthed a consistent pattern in their examination of opinions in which at least one justice stated his desire to strike an act of government. Liberals vote to strike laws that liberal litigants (defendants in criminal cases, women and minorities in civil rights cases, etc.) want struck, while conservatives vote to strike laws that conservative litigants (the government in criminal cases, those opposed to women and minorities in civil rights cases, etc.) want struck. ${ }^{22}$ Lindquist and her 
co-authors show a similar pattern for state and federal laws as well for the actions of administrative agencies (Lindquist, Smith, \& Cross, 2007). All else being equal, the probability of Justice Scalia's voting to strike a liberal agency policy directive is about .39; if the agency directive is conservative, the odds fall to .24. The figures for the liberal Justice Stevens are even starker: he will almost always uphold a liberal policy but more often than not strike a conservative one (Lindquist et al., 2007). Even justices who profess a commitment to judicial "restraint" are not immune. Long ago, Spaeth famously shattered the myth that Felix Frankfurter-a justice whose name was "synonymous with the concept of judicial restraint" - adhered to that philosophy (Spaeth, 1964). By systematically examining his votes in cases involving labor and business regulation, Spaeth showed that Frankfurter's purported "judicial restraint" was "thoroughly subordinated to [his] attitudes." He was "a staunch economic conservative" who was willing to strike down laws that impinged on his policy preferences (Segal \& Spaeth, 2002, pp. 409-17). For example, during the first seven terms of the Warren Court, Frankfurter voted to strike down only $9 \%$ of state regulations of labor, a position consistent with his professed judicial restraint. But he was willing to strike down $69 \%$ of state regulations of business (Spaeth, 1979, pp. 78-79).

These analyses may reach similar conclusions, but to some scholars, they suffer from a nontrivial problem: they tend to treat judges as operating within an ideological vacuum of sorts, making decisions without considering the preferences and likely actions of their colleagues. Recognizing that that may be unrealistic for collegial courts, social scientists have turned their attention to how judges serving on the same panel or court may affect one another.

One strand of this research focuses less on the ideology of the individual judges and more on how their ideology works to affect their colleagues. Recall that for most areas of the law they examined, Sunstein and colleagues (2006) found some evidence of ideological dampening, which occurs when a judge sits with two judges who do not share his partisan affiliation. They also found evidence of ideological amplification, such that judges sitting on homogeneous Democratic or Republican panels tend to be extremely ideological. Sunstein and colleagues (2006) point out that litigants defending affirmative action programs have a one-in-three chance of prevailing when the panel is full of Republican appointees. The odds increase to four in five when three Democrats sit on the panel. Finding that similar panel effects pervade many other areas of the law, they conclude that the "political party of the presidents who appointed the other two judges on the panel is at least as good a predictor of how individual judges will vote" as the party affiliation of that individual judge's appointing president (p.10). 
Why ideological panel effects seem to exist is a contested matter. One explanation for ideological amplification, proposed by Cross and Tiller (1998), is that homogeneous panels lack a "whistleblower" — a judge whose preferences differ from the majority's and who will expose the majority's extremeness to the rest of the circuit or to Supreme Court. Mixed panels, in contrast, will reach more moderate decisions because, by definition, a potential whistleblower is always present. Another explanation is far less nefarious. The idea is that any ideological effect on panels is a result of judges seeking to accommodate their colleagues and not of strategic behavior.

Whatever the explanation, it is clear that panel effects are not limited to panels; they seem to operate to varying degrees on all collegial courts. When Supreme Court justices vote to grant or deny certiorari, they calculate the likelihood that they will prevail at the next stage, in the decision on the merits. Making that calculation requires the justices to take into account the preferences and likely actions of their colleagues, and there is some evidence that they do just that. Even after taking into account the many factors that may affect the justices' case selection decisions, such as the existence of a circuit split, Caldeira and his colleagues (1999) find that the justices often cast votes that amount to "defensive denials." That is, they vote to deny cert in cases they would otherwise like to reverse when they believe the case will not prevail on the merits. They also find evidence of "aggressive grants," when the Court votes to hear a case on which they agree with the lower court ruling and believe a majority will affirm.

Finally, there are many areas of inquiry concerned with understanding the forces that may tame ideological decision making. At the onset we mentioned stare decisis. There are also studies that examine whether judges who must stand for reelection attend to their constituents' preferences when they make their decisions. Substantial evidence now suggests that they do. Hewing perhaps to the Japanese axiom that the nail that sticks out is mostly likely to be hammered down, popularly elected judges are more likely to suppress dissent. They do not want to be "singled out for possible electoral sanction" (Hall, 1987, p. 1117), especially if their views are inconsistent with their constituents.

Relatedly, and perhaps more importantly, research indicates that even after controlling for their own ideological predilections, elected judges tend to reach decisions that reflect popular sentiment. In one recent analysis, the authors report that all else being equal, state supreme court justices are 13\% less likely to reverse death sentences when their constituents are strongly supportive of the capital punishment (Brace \& Boyea, 2008). Likewise, a study of all murders recorded by the Chicago police reveals that convicted defendants were significantly more likely to be sentenced to death in a judge's reelection 
year (Brooks \& Raphael, 2002). A scrupulous analysis of 22,000 trial court sentences in assault, rape, and robbery convictions has found that sentences grow significantly longer as a judge's reelection comes nearer. The authors attribute 1,800 to 2,700 additional years in prison time to elections (Huber \& Gordon, 2004). On the civil side, a study of 7,000 cases across 48 states demonstrates that elected judges are more likely to redistribute wealth from out-of-state businesses to in-state plaintiffs. The expected total award is about $\$ 240,000$ higher (Helland \& Tabarrock, 1999).

What we have presented is just a taste of the empirical literature on ideology. The project is now so large, encompassing scholars in no fewer than three disciplines, that it is impossible to review it all here. That is not to say that all the important work is done, nor is it to say that the methods and the findings we have reported are wholly uncontroversial. Many areas remain unplowed. Methodological challenges remain. And empirical scholars have yet to deal with some of the normative critiques hurled at studies that emphasize ideology. Yet the last several decades have seen marked advances in the study of ideology and judicial behavior, and no doubt more will follow even before this book appears in print.

\section{NOTES}

* We are grateful to the National Science Foundation and Northwestern University School of Law for research support.

1. Political scientists do, however, disagree over the definition of ideology. For a range of possibilities, see Gerring (1997), though we think Bawn's (1999) approach captures contemporary thinking: "Ideology is enduring system of beliefs, prescribing what action to take in a variety of political circumstances" (p. 305). In this chapter, our usage of ideology relates to one's position along the political spectrum.

2. Converse (1964) argues, however, that American voters typically lack the attitudinal constraint necessary for ideological behavior.

3. Most political scientists credit C. Herman Pritchett with establishing the field of judicial behavior in the 1940s (e.g., Pritchett, 1941, 1948).

4. For more on this point, see Epstein, Knight, and Martin (2003).

5. Here and throughout, we emphasize voting on the merits of cases. In part IV, we briefly describe research that asks whether ideological considerations infiltrate other choices that judges make.

6. For the leading contemporary statement of this account, called "the attitudinal model," see Segal and Spaeth (2002).7.For a description of strategic accounts, see Epstein and Knight (1998).8. We should offer a caveat to this claim. While it is true that under the attitudinal account judges pursue one and only one goal 
(policy), on the strategic account it is up to the researcher to specify a priori the judges' goals; the researcher may select any motivation(s) she believes the particular judges hold. Nonetheless, virtually every existing strategic account of judicial decisions posits that judges pursue policy-that is, their goal is to see public policy, the ultimate state of the law, reflect their preferences. One (important) exception is Ferejohn and Weingast (1992), which posits that judges may have jurisprudential goals.

9. Another advantage of the party-based approach is that it is exogenous of (that is, not caused by) judicial decisions, a point to which we return momentarily.

10. Law professors seem more inclined to continue to rely on this approach than political scientists (see, e.g., Sunstein, Schkade, Ellman, \& Sawicki, 2006; Cross \& Tiller, 1998; Heise \& Sisk, 2005).

11. Carter's score is 60.3, Nixon's is 47.7, and Johnson's is 78.2 (Segal, Timpone, \& Howard, 2000).

12. To provide but one example, Haire, Humphries, and Songer (2001) report that: "In contrast to Reagan-Bush appointees, the Clinton appointees offered substantially more support to the liberal position in civil rights claims. When voting on criminal and economic issues, [however], Clinton judges generally adopted positions that were strikingly similar to those taken by judges appointed by moderate Republican [Presidents]" (p. 278).

13. See Goldman (1997) arguing, on the basis of detailed archival work, that presidents seek to advance one or some combination of three agendas-personal, partisan, or policy—when they make judicial nominations. "Personal agenda" refers to using the nominating power to please a friend or associate; "partisan agenda" means using nominations as vehicles for shoring up electoral support for their party or for themselves within their party; and "policy agenda" is about using nominations to enhance the substantive policy objectives of an administration.

14. Party-based approaches are, of course, exogenous.

15. The norm of senatorial courtesy grants home-state senators of the president's party near veto-like authority over lower court appointments from their state. If they declare that a nominee is repugnant to them, other senators will support that decision, knowing that they will receive the same courtesy about nominees from their state.

16. For the senators' and presidents' ideology, Giles, Hettinger, and Peppers (2001) rely on Keith Poole's Nominate Common Space scores, which are the result of a scaling algorithm that takes a set of issue scales (in this case, a set of measures for representatives, senators, and presidents) fit term by term. Using legislators that have served in both chambers, presidents that have served in the legislature, and stated presidential vote intentions, the algorithm provides an ideal point for all representatives, senators, and presidents.

17. The scores are available at: http:/ / mqscores.wustl.edu. For more details about their creation, see Martin and Quinn (2002). 
18. The database is at http://supremecourtdatabase.org; the documentation is at: http://scdb.wustl.edu/documentation.php.

19. An additional difficulty is that ideological labels may be time-dependent, bound to a particular historical era. For example, Muller v. Oregon (1908) upheld a state law that set a maximum number of hours women (but not men) could work. How would 21st-century Americans classify this decision? Many would probably regard it as conservative because it seems to patronize and protect women. In the early 1900s, however, many considered Muller a liberal ruling because it allowed the government to regulate business.

20. Using a $t$-test, $p<05$.

21. Nearly all systematic quantitative work on the U.S. Supreme Court suggests that the issue space can be characterized reasonably well by a single dimension. For instance, Grofman and Brazill (2002) note that the single-dimension solution explains much of the justices' voting behaviors. The same, we might add, holds for Congress. Poole and Rosenthal (1997) and Poole (2007) both report that voting in Congress is almost exclusively one-dimensional, such that "a single dimension accounts for about 92 percent of roll call voting" (Poole \& Rosenthal, 1997, p. 437).

22. This would not have come as a surprise to Justice Thurgood Marshall. In response to the Court's decision in Payne v. Tennessee (1991), which overruled Booth v. Maryland (1987), and South Carolina v. Gathers (1989), Marshall quipped: "It takes little real detective work to discern just what has changed since this Court decided Booth and Gathers: this Court's own personnel."

\section{REFERENCES}

Anderson, J. (1981, December 4). Syndicated column, in The Courier (Yavapai, AZ), p. 3.

Bawn, K. (1999). Constructing "us": Ideology, coalition politics, and false consciousness. American Journal of Political Science, 43, 303-34.

Bergara, M., Richman, B. D., \& Spiller, P. T. (2003). Modeling Supreme Court strategic decision making: The congressional constraint. Legislative Studies Quarterly, $28,247-80$.

Booth v. Maryland, 482 U.S. 496 (1987).

Brace, P., \& Boyea, B. D. (2008). State public opinion, the death penalty and the practice of electing judges. American Journal of Political Science, 52(2), 360-72.

Brenner, S., \& Spaeth, H. J. (1995). Stare indecisis: The alteration of precedent on the U.S. Supreme Court 1946-1992. Cambridge, MA: Cambridge University Press.

Brooks, R.W., \& Raphael, S. (2002). Life terms or death sentences: The uneasy relationship between judicial elections and capital punishment. Journal of Criminal Law and Criminology, 92, 609-40.

Caldeira, G. A., Wright, J. R., \& Zorn, C. J. W. (1999). Sophisticated voting and gate keeping in the Supreme Court. Journal of Law, Economics and Organization, 15, 549-72. 
Converse, P. (1964). The nature of belief systems in mass publics. In D. Apter (Ed.), Ideology $\mathcal{E}$ discontent (pp. 206-61). New York: Free Press of Glencoe.

Cross, F. B., \& Tiller, E. H. (1998). Judicial partisanship and obedience to legal doctrine: Whistleblowing on the Federal Courts of Appeals. Yale Law Journal, 107, 2155-76.

Epstein, L., \& Knight, J. (1998). The choices justices make. Washington, DC: CQ Press.

Epstein, L., Knight, J., \& Martin, A. D. (2003). Childress Lecture Symposium: The political (science) context of judging. St. Louis University Law Journal, 47, 783-17.

Epstein, L., Martin, A. D., Quinn, K., \& Segal, J. A. (2007). Ideological drift among Supreme Court justices. Northwestern University Law Review, 101, 1483-542.

Epstein, L., \& Mershon, C. (1997). Measuring political preferences. American Journal of Political Science, 40(1), 261-94.

Epstein, L., Segal, J. A., Spaeth, H. J., \& Walker, T. G. (2007). The Supreme Court compendium (4th Ed.). Washington, DC: CQ Press.

Eskridge, W. N. Jr., (1991a). Overriding Supreme Court statutory interpretation decisions. Yale Law Journal, 101, 331-445.

Eskridge, W. N. Jr., (1991b). Reneging on history?: Playing the court/congress/ president civil rights game. California Law Review, 79, 613-84.

Ferejohn, J., \& Weingast, B. (1992). A postive theory of statutory interpretation. International Review of Law and Economics, 12, 263-79.

Gerring, J. (1997). Ideology: A definitional analysis. Political Research Quarterly, 50, 957-94.

Giles, M., Hettinger, V., \& Peppers, T. (2001). Picking federal judges: An alternative measure of preferences for federal judges. Political Research Quarterly, 54, 623-41.

Goldman, S. (1966). Voting behavior on the United States Courts of Appeals, 19611964. American Political Science Review, 60, 374-83.

Goldman, S. (1997). Picking federal judges. New Haven: Yale University Press.

Grofman, B., \& Brazill, T. (2002). Identifying the median justice on the Supreme Court through multidimensional scaling: Analysis of "natural courts" 19531991. Public Choice, 112, 55-79.

Haire, S. B., Humphries, M. A., \& Songer, D. R. (2001). The voting behavior of Clinton's courts of appeals appointees. Judicature, 84, 274-81.

Hall, M. G. (1987). Constituent influence in state Supreme Courts. Journal of Politics, $49,1117-24$.

Hansford, T. G., \& Spriggs, J. F., II. (2006). The politics of precedent on the U.S. Supreme Court. Princeton, NJ: Princeton University Press.

Helland, E., \& Tabarrock, A. (1999). Court politics: The political economy of tort awards. Journal of Law and Economics, 42, 157-88.

Heise, M., \& Sisk, G. C. (2005). Judges and ideology: Public and academic debates about statistical measures. Northwestern University Law Review, 99, 745-803.

Howard Jr., J. W. (1981). Courts of Appeals in the federal judicial system. Princeton, NJ: Princeton University Press. 
Huber, G. A., \& Gordon, S. C. (2004). Accountability and coercion: Is justice blind when it runs for office? American Journal of Political Science, 48, 247-63.

Jacobi, T. (2009). Competing theories of coalition formation and case outcome determination. Journal of Legal Analysis, 1, 411-35.

Johnson, K. (1993, March 15). The street fighter and the professor: Moynihan and D'Amato: A loyal pair. New York Times, p. B1.

Kim, P. T. (2009). Deliberation and strategy on the United States Courts of Appeals: An empirical exploration of panel effects. University of Pennsylvania Law Review, 157, 1319-81.

King, G., Keohane, R. O., \& Verba, S. (1994). Designing social inquiry: Scientific inference in qualitative research. Princeton, NJ: Princeton University Press.

Lindquist, S. A., Smith, J. L., \& Cross, F. B. (2007). The rhetoric of restraint and the ideology of activism. Constitutional Commentary, 24, 103-26.

McGuire, K. T., \& Vanberg, G. (2005). Mapping the policies of the U.S. Supreme Court: Data, opinions, and Constitutional law. Paper Presented at the 2005 Annual Meeting of the American Political Science Association, Washington, DC.

Martin, A. D., \& Quinn, K. M. (2002). Dynamic ideal point estimation via Markov Chain Monte Carlo for the U.S. Supreme Court, 1953-1999. Political Analysis, 10(2), 134-53.

Martin, A. D., \& Quinn, K. M. (2005) Can Ideal Point Estimate be used as explanatory variables? Retrieved from http://mqscores.wustl.edu/media/ resnote.pdf.

Martin, A. D., \& Quinn, K. M. (2007). Assessing preference change on the U.S. Supreme Court. Journal of Law, Economics and Organization, 23, 365-85.

Muller v. Oregon, 208 U.S. 412 (1908).

Payne v. Tennessee, 501 U.S. 808 (1991).

Poole, K. (2007). Changing minds? Not in Congress! Public Choice, 131(3), 435-51.

Poole, K., \& Rosenthal, H. (1997). Congress: A political-economic history of roll-call voting. New York: Oxford University Press.

Posner, R. A. (2008). How judges think. Cambridge, MA: Harvard University Press.

Pritchett, C. H. (1941). Divisions of opinion among justices of the U.S. Supreme Court. American Political Science Review, 35, 890-98.

Pritchett, C. H. (1948). The Roosevelt Court. New York: Macmillan.

Randazzo, K. A. (2008). Strategic anticipation and the hierarchy of justice in the U.S. District Courts. American Politics Research, 36(5), 669-93.

Schanzenbach, M. M., \& Tiller, E. H. (2007). Strategic judging under the U.S. sentencing guidelines: Positive political theory and evidence. Journal of Law, Economics, and Organization, 23(1), 24-56.

Segal, J. A. (2008). Judicial behavior. In K. E. Whittington, R. D. Kelemen, \& G. A. Caldeira (Eds.), The Oxford handbook of law and politics (pp. 19-33). New York: Oxford University Press.

Segal, J. A., \& Cover, A. D. (1989). Ideological values and the votes of U.S. Supreme Court Justices. American Political Science Review, 83, 557-65. 
Segal, J. A., \& Spaeth, H. J. (2002). The Supreme Court and the attitudinal model revisited. New York: Cambridge University Press.

Segal, J. A., Timpone, R. J., \& Howard, R. M. (2000). Buyer beware?: Presidential success through Supreme Court appointments. Political Research Quarterly, 53, $557-62$.

Songer, D. R., \& Haire, S. (1992). Integrating alternative approaches to the study of judicial voting: Obscenity cases in the U.S. Courts of Appeals. American Journal of Political Science, 36, 963-82.

South Carolina v. Gathers, 490 U.S. 805 (1989).

Spaeth, H. J. (1964). The judicial restraint of Mr. Justice Frankfurter. Midwest Journal of Political Science, 8, 22-38.

Spaeth, H. J. (1979). Supreme Court policy making: Explanation and prediction. San Francisco: W.H. Freeman.

Stimson, J. (1991). Public Opinion in America. Boulder: Westview.

Sunstein, C., Schkade, D., Ellman, L. \& Sawicki, A. (2006). Are judges political? An empirical analysis of the federal judiciary. Washington, DC: Brookings Institution Press.

Wisconsin v. Mitchell, 508 U.S. 476 (1993). 